\title{
"La misma realidad de cada lugar es diferente" ("The same reality of each place is different"): A case study of an organic farmers market in Lima, Peru
}

\author{
Kevin Cody ${ }^{a}$ \\ University of California, Santa Cruz
}

\begin{abstract}
Submitted September 1, 2014 / Revised November 5 and December 31, 2014 /
Accepted January 5, 2015 / Published online March 9, 2015

Citation: Cody, K (2015). "La misma realidad de cada lugar es diferente" ("The same reality of each place is different"): A case study of an organic farmers market in Lima, Peru. Journal of Agriculture, Food Systems, and Community Development, 5(3), 53-69. http://dx.doi.org/10.5304/jafscd.2015.052.011
\end{abstract}

Copyright (C) 2015 by New Leaf Associates, Inc.

\begin{abstract}
Studies of alternative food networks have proliferated in Europe and North America while relatively little attention has been paid to similar networks in the global South. An organic farmers market in Lima, Peru, serves as a case study to examine developments in the domestic market for organic produce in Peru. Drawing from interview data and participant observations with pioneering organic farmers and nongovernmental organizations (NGOs) affiliated with the farmers market, this paper investigates how the context of a developing country reaffirms and/or challenges alternative food network (AFN) conceptualizations derived from Northern research sites. The aim of this

\footnotetext{
${ }^{a}$ Department of Sociology, University of California, Santa Cruz; 1156 High Street; Santa Cruz, California 95064 USA.

Kevin Cody is now at the University of Northern Colorado in Environmental and Sustainability Studies; Campus Box 36; Greeley, Colorado 80639 USA; +1-831-706-6614; kevin.cody@unco.edu
}

research is to expand our understanding of alternative food networks in a global context. Findings suggest that while the farmers market in Peru replicates many challenges and opportunities ascribed to similar market-based initiatives in the global North, the developing country context encourages a different reading of these similarities. This exploratory examination of an AFN in Peru suggests that this organic farmers market has created novel economic opportunities for ecologically minded entrepreneurs and organic farmers in rural communities far from the point of sale. Although constrained by a relatively small demographic of affluent, conscientious consumers, the organic market demonstrates the potential to improve rural livelihoods while raising consumer awareness about the benefits of organic agriculture.

\section{Keywords}

farmers market, organic agriculture, alternative food networks, Peru 
The long row of vendors at the farmers market present an array of fruits and vegetables, hand-ground coffee, and vegan wraps. There are vendors selling artisan bandicrafts and books on nutrition, and organizations promoting organic agriculture. Artisan cheeses and breads are complemented by fresh-cut salad greens and a colorful array of potatoes. In the center of the row a number of people on folding chairs listen attentively to a presentation on micronutrients and the bealth benefits of eating organic produce. Someone is passing out fliers for an upcoming weekend-long course on permaculture. Customers at the market reflect the demographics of this neighborhood: affluent locals and tourists from Europe and North America. This market is at once completely familiar, given it could just as well be somewhere in California, and yet totally foreign. After all, we are in Peru.

The organic farmers market (FM) described above takes place in a relatively affluent district of Lima, Peru, and is the most economically successful and well-attended of its kind. Known as a Bioferia, it is unlike the other open-air produce markets that are commonplace throughout the country. The most notable distinction is the organic certification claimed by the more than 50 vendors at the market, which is composed mostly of individual entrepreneurs and farmers associations. As with FMs in the U.S., farmers here can charge more for their products given its location in Miraflores, an affluent district of Lima, and the increasing consumer demand for organic produce. At first glance the market appears to be a win-win scenario: consumers gain access to fresh organic produce, and producers benefit from a price premium, supporting a small-farm sector increasingly marginalized by agro-industrialization (Flores, 2014. Scholarship from the global North, however, has championed these kinds of markets for both their social embeddedness and the economic opportunities they provide (Brown \& Miller, 2008; Feenstra \& Lewis, 1999; Feenstra, Lewis, Hinrichs, Gillespie, \& Hilchey, 2003; Gillespie, Hilchey, Hinrichs, \& Feenstra, 2007), and problematized such marketbased approaches to promoting agrarian change (DeLind, 2002; Guthman, 2008; Hinrichs, 2000; Hinrichs \& Allen, 2008).

This research draws upon Northern-based scholarship on alternative food networks (AFNs) to examine aspects of a similar empirical context in Peru: the domestic market for organic produce. I focus on a popular organic FM (or Bioferia) modeled after a type of FM found in the global North that caters to affluent, health-motivated, environmentally minded consumers. An emergent scholarship has provided initial insights into the potential for AFNs in the North and South to support sustainable food systems that encompass diverse economic, racial, and cultural backgrounds (Abrahams, 2007; Freidberg \& Goldstein, 2011). However, given the Northern geographic bias in the scholarship, there is relatively more to learn about how AFNs are being developed in the global South and how these developments might contribute to "globally useful conceptualizations of AFN" (Abrahams, 2007, p. 95). Thus, this paper examines how the context of a developing country reaffirms and/or challenges AFN conceptualizations derived from Northern research sites, ultimately drawing attention to how expanding the scope of analysis to encompass the global South requires reconceptualizing the workings and implications of AFNs in a global context.

Based on critical and promotional scholarship on AFNs, I consider how "place-based contingency shapes outcomes" (Guthman, 2008, p. 1172) in the development of Peru's domestic market for organic produce. Unsurprisingly, the Bioferia reproduces some of the problematic tendencies also found in Northern markets: the Bioferia caters to a relatively small population of affluent Peruvians and foreigners, while "organic nongovernmental organizations (NGOs)" 1 promote farmer livelihoods and market integration over food security for rural and urban populations. Moreover, organic NGOs' emphasis on consumer choice may impede collective action on issues related to social justice while reifying organics as the domain of privileged elite. As one of the pioneering organic farmers in this study remarked, "The same reality of each place is different," provoking a closer examination into not only the similarities between FMs in the

\footnotetext{
${ }^{1}$ I use this term to describe the loose assortment of NGOs promoting organic agriculture and new marking opportunities for small-scale, ecologically oriented farmers.
} 
North and this market in Lima, but also the context surrounding the Bioferia that makes it so distinct.

One reading of the Bioferia is to view it as an example of how market forces tend to subvert agrarian values and create subjects with a myopic focus on their own personal choices and well-being (Guthman, 2003, 2008). However, drawing from Gibson-Graham (2006) and the concept of "reading for difference rather than dominance" (p. xxxi), many of these critical analyses are complicated by the unique Peruvian context in which this market has emerged. I contend that expanding the geographic frame of reference of AFNs opens up discussions of poverty, development, and the "historical forces" and "contemporary conditions" under which alternative food initiatives either "take root or whither" (Freidberg \& Goldstein 2011, p. 24). This exploratory examination of an emblematic instance of AFNs in Peru shows that the Bioferia has created novel economic opportunities for ecologically minded entrepreneurs and organic farmers in rural communities far from the point of sale. Although constrained by a relatively small class of affluent and conscientious consumers, the domestic market for organic foods in Peru has the potential to improve rural livelihoods by ascribing economic value to already existing organic farming practices, while at the same time inspiring critical reflection among organizers and advocates about the limitations of market-based agrarian change.

First, I review relevant literature about the challenges and opportunities associated with FMs and organic agriculture, introducing the concept of "reading for difference" as a strategy for revealing an alternative interpretation of AFNs in the global South. After an overview of my research methods, I provide background on the development of an organic sector in Peru focusing on a popular Bioferia and organic NGOs. ${ }^{2}$ In my findings section, I first highlight the challenges associated with the growth of the organic sector, including the questionable sustainability of institutions developed to support emerging organic markets, and then show

${ }^{2}$ I focus principally on two different organic NGOs: The National Association of Ecological Producers (ANPE), and Huayuna. how the Bioferia has opened up new opportunities for ecologically oriented producers and their rural communities. I conclude by showing how this case study lends itself to an alternative reading of critical scholarship on FMs and organic agriculture, despite the similarities between this market in Peru and other upscale organic markets in the global North.

\section{Farmers Markets and Organic Agriculture: Assessing Market-based Agrarian Reforms} Northern-based AFNs are defined by processes that reorient social and spatial dimension of food systems, bring producers and consumers into closer contact, provide economic opportunities for small-scale farmers, and support visions of economic, social and environmental sustainability (Goodman \& Goodman, 2009; Jarosz, 2007; Renting, Marsden, \& Banks, 2003; Watts, Ilbery, \& Maye, 2005). Farmers markets have become a hallmark of AFNs and are associated with wideranging benefits, from economic gains for smallscale farmers unable to access larger wholesale markets (Brown \& Miller, 2008; Gillespie et al., 2007; Griffin \& Frongillo, 2003; Hardesty \& Leff, 2010; Thilmany \& Watson, 2004), to the cultivation of trust, reciprocity, and regard between producers and consumers (Lee, 2000; Sage, 2003).

Another market-based mechanism said to facilitate agrarian change, certified organic agriculture $^{3}$ has been heralded as a boon to small and medium-sized farmers who receive a price premium for their certified organic products (International Fund for Agricultural Development [IFAD], 2003; Pugliese, 2001) while also benefiting the environment through reductions in the use of synthetic fertilizers and pesticides (Allen \& Kovach, 2000). Organic agriculture in the global South has evolved along a very different trajectory than the North, where the vast majority of organic produce is consumed. In the global South, organic agriculture is primarily export-oriented, destined for markets in North America and Europe (Willer

\footnotetext{
3 Throughout this research, "organic agriculture" refers specifically to that which has been certified in one form or another, as compared to a de facto organic agriculture common among more traditional subsistence farmers.
} 
\& Lernourd, 2014), and promoted by NGOs as a way to improve rural livelihoods of small-scale farmers (Beban, 2014; Flores, 2014; IFAD, 2003; Parrott, Olesen, \& Høgh-Jensen, 2006; Pugliese, 2001; Thavat, 2011; Vaarst, 2010). The results, however, have been mixed. Programs developed to support organic exports in the global South have proven problematic for their imposition of Northern-based market and regulatory requirements on rural communities undergoing their own unique processes of agrarian transition (Beban, 2014; Raynolds, 2004; Thavat, 2011). And while there is a well established and occasionally critical literature examining the impacts of organics and fair trade in export commodities like coffee (Bacon, 2005; Beuchelt, \& Zeller, 2011; Jaffee, 2007; Raynolds, 2004), there has been very little work done in exploring emerging domestic markets for organic produce and corresponding AFNs in the global South (Abrahams, 2007; Freidberg \& Goldstein, 2011). This research helps to fill this gap by asking how and to what extent these Southern markets reflect similar tendencies and challenges associated with market-based agrarian reforms found in the global North.

The alleged social, economic, and environmental benefits of FMs and organic agriculture have been problematized by AFN scholars in the global North who are skeptical of the progressive nature of market-based socio-agrarian reforms (Alkon, 2008; Allen \& Guthman, 2006; DeLind, 2002; Guthman, 2008; Guthman, Morris, \& Allen, 2006; Hinrichs, 2000; Hinrichs \& Allen, 2008; Slocum, 2007). This critical scholarship on AFNs points to how an emphasis on market-based solutions fails to address systematic social injustice and reinforces neoliberal emphases on individual choice and entrepreneurialism as sufficient drivers of social change (Alkon \& Mares, 2012; Guthman, 2008; Hinrichs \& Allen, 2008). Farmers markets in particular have been critiqued for being overly determined by market mechanisms as opposed to the social and ecological values they are said to represent (DeLind, 2002; Hinrichs, 2000). According to DeLind (2002), the FM is a market-based initiative where "the principal players (however friendly and personalized) are still producers and consumers; their basic identities are still framed by the economic or commercial transaction" (p. 218). This is not to say that the social relations and ecological values embedded within the market are nonexistent, but rather to acknowledge the tendency of the market to subsume these types of social values. With regard to the market for organic agriculture, Allen and Kovach (2000) caution that over the long run, ecological and social benefits are likely to be compromised by the incursion of largescale agrarian capital. Indeed, this trend is evident in the conventionalization of organics across the globe (Buck, Getz, \& Guthman, 1997; Coombs \& Campbell, 1998; Raynolds, 2004).

Another critique of FMs is that they are illsuited to address food justice ${ }^{4}$ concerns because of the tendency to privilege producer livelihoods over those of low-income consumers (Guthman et al., 2006). Allen (2004) claims that such "farmcentrism" overinflates the importance of farmers in the alternative food movement to the exclusion of, for example, food-industry and farm workers ( $p$. 120). That the vast majority of organic exports from the global South are consumed in the North further illustrates the strong relationship between affluence and organic consumption (Flores, 2014). As this case from Peru will demonstrate, the tendency for AFN organizers and advocates to privilege farmer livelihoods and to rely on affluent consumers is evident in organic FMs in the North as well as the South.

\section{"Reading for Difference"}

At first glance it appears that the above U.S.-based critiques apply handily to developments in Peru's organic sector. However, the application of these critiques to the upscale FM in Peru depends upon how findings are interpreted, or "read." This paper adopts a "reading for difference" approach (Gibson-Graham, 1996, 2006; Harris, 2009), which seeks to avoid reinscribing neoliberal emphases on market-based reforms, individual consumption, and entrepreneurialism. According to Harris, activist/scholars have a role to play in cultivating

\footnotetext{
${ }^{4}$ According to Alkon and Mares (2012), "the concept of food justice speaks to the multiple ways that racial and economic inequalities are embedded within the production, distribution, and consumption of food" (p. 348).
} 
alternatives to neoliberalism through our theoretical engagements. He argues that,

by adopting Gibson-Graham's practice of 'reading for difference rather than dominance' (2006, p. xxxi) we might learn to read the landscape of alternative food politics not as reproducing the dominance of hegemonic neoliberalism, but as populated by a variety of emergent institutions and practices (paraphrasing Gibson-Graham, 2006, p. 54). In so doing, we might better acknowledge attempts to imagine and enact a food politics that achieves different socio-environmental justice outcomes to those of conventional food systems, and offer a more constructive academic critique. (Harris, 2009, p. 60)

Geographical and historical locations, then, are essential to determining difference in the case of alternative food initiatives like the FM, as demonstrated by case studies of emerging AFNs in South Africa (Abrahams, 2007) and a community supported agriculture (CSA) box scheme in Kenya (Freidberg \& Goldstein, 2011). As the following "reading for difference" analysis demonstrates, the organic FM in Peru has - rather than merely replicating the challenges pointed to in Northern AFMs - opened up a variety of unforeseen opportunities to further social and ecological commitments to the burgeoning organic movement.

\section{Methodology and Case Selection}

Data collected for this research reveal aspects of Peru's domestic market for organic products through interviews and participant observation with individuals and institutions associated with one of the country's most well-established Bioferias. My entry point into this research, and the subsequent methodology, is a result of working closely with a group called the Multinational Exchange for Sustainable Agriculture (MESA). ${ }^{5}$ MESA alumni

\footnotetext{
${ }^{5}$ In this program participants from around the world (though mostly from Peru and Ecuador) come to live and work on a variety of U.S. organic farms for approximately nine months. The intention is to provide them with opportunities to learn
}

constituted a convenience sample of individuals working in organic agriculture in and around Lima. They also provided access to communities of farmers participating in the Bioferia and introduced me to the staff of two NGOs (the National Association of Ecological Producers [ANPE] and Huayuna) and members of two organic cooperatives. Numerous alumni are particularly active in an agricultural region near the district of Mala, approximately one hundred kilometers (62 miles) south of the city. Mala became an epicenter of this research, much as it has been for the organic movement in Peru since the late 1990s, when Huayuna began offering trainings in organic methods and helping organize two organic cooperatives.

Over the course of three months, spanning two research trips in 2011 and 2009, I made frequent observations at the Bioferia. I also conducted semistructured interviews with eight MESA alumni, three pioneering organic farmers, and several representatives from ANPE and Huayuna. Informal interviews were conducted with members of two organic cooperatives as well as dairy farmers in a rural community supplying the milk for an artisanal cheese-making operation at the Bioferia. Informal conversations with customers and vendors provided data on the demographics of the market and the motivations of producers and consumers to attend the market. In-depth data was collected with four MESA alumni in particular with whom I conducted multiple interviews, in addition to observing their work on their respective farms and in the rural communities where they live. Each of these individuals is engaged in different productive endeavors associated with the Bioferia: one is an entrepreneur, another is a farmer and market organizer, and two more work as laborers on an organic farm, in addition to selling produce at the market. All of these interviews were recorded, transcribed, and coded in an effort to derive common themes that emerged in the form of both challenges and opportunities in the domestic market for organics in Peru.

valuable skills and gain experiences they will be able to apply once back in their home countries. 


\section{Background: Organic Markets and NGOs in Peru}

There are a number of distinctive features of an emerging AFN in Peru that have contributed to the formation of the Bioferia in Miraflores. Organic agriculture in Peru, like in many other developing countries around the world, is primarily exportoriented, although there is evidence of a growing movement focused on organic production for domestic markets in the form of high-end supermarkets, natural food stores, and FMs like the Bioferia (Flores, 2014; Olsen, 2008; "Organic Products and Market" [Productos Ecológicos y Mercado], 2012).

While as little as $5 \%$ of organic products in Peru is sold in domestic markets (Olsen, 2008), the volume of sales fails to represent broader cultural and political trends within Peru's emergent AFN.

In the cultural sphere, the domestic market for organic produce has been given a significant boost by the Peruvian Gastronomy Society and the rise of a movement celebrating Andean cuisine (Flores, 2014). One initiative of the Gastronomy Society is to create farmer-chef alliances that support the production of indigenous crops and ecological or organic methods of production. In an interview with the executive director of ANPE, Peru, he said: "The Peruvian gastronomy boom is another phenomenon that is pushing the growth of the organic movement and organic production. It is an important engine. They are now looking for certified organic products, mostly for restaurants." Famous Peruvian chefs like Gastón Acurio have been enormously influential in drawing international attention to Peruvian cuisines and inspiring the use of organic and indigenous products in high-end restaurants in Peru. An event started by Acurio and others called La Mistura, a gastronomy fair in Lima celebrating regional cuisine and agricultural products of Peru, has drawn as many as 500,000 attendees in recent years (Mistura, 2014). Events like La Mistura illustrate distinct aspects of an emerging AFN in Peru focused on the country's diverse agricultural history and traditions.

In the political sphere, efforts are underway to promote organic and sustainable food production as a way to improve farmer livelihoods and ensure environmental and consumer safety. The Peruvian Congress established a law promoting organic agri- culture $^{6}$ and instituted a 10 -year moratorium on all genetically modified organisms (GMO) foods (Murphy, 2013). Various organic certification agencies $^{7}$ are managed by SENASA (the National Agrarian Health Service), in coordination with private-sector NGOs. In 2001, the public and private sectors together created the National Organic Products Commission, designed to implement certification standards from the point of production to the point of sale. NGOs like ANPE have introduced bills on food sovereignty to the national legislature. Overall, the growing domestic market for organic produce in Peru provides an opportunity to expand analyses of AFNs that encompass geographic areas in the global South. An especially intriguing development in Peru is the emergence of organic farmers markets.

\section{"Las Bioferias"}

The Bioferias, or organic farmers markets, are one of the most visible and influential elements of Peru's domestic market for organic produce. Outdoor markets selling traditional and local produce are the norm throughout rural Peru. What makes the Bioferias distinct is their explicit focus on the ecologico, or organic, methods of production. All the produce at the Bioferia is alleged to be grown without pesticides or herbicides, thus providing a "healthier" product for the consumers who choose to pay a premium for their produce. These organic FMs are a main distribution outlet for organic produce and one of the most visible indicators of what could be considered an emerging AFN in Peru.

There are Bioferias in all parts of Peru, ${ }^{8}$ but the

\footnotetext{
6 The Law for the Promotion of Organic and Natural Production (Law No. 29196) is meant to promote organic and sustainable agriculture as an avenue for poverty reduction, food security, and environmental conservation (Ferreira, 2008)

7 There are currently five private certification agencies recognized by U.S. and European regulators: Bio Latina, BCS OKO, Control Union-SKAL, IMO Control, and OCIA. Bio Latina works in Bolivia, Columbia, Peru, and Nicaragua and is the primary certification agency for domestic organics in Peru; the others work mostly with large export markets.

8 There are Bioferias in other, less affluent districts of Lima and in other regions of Peru, which have achieved limited success according to farmers at the market in Miraflores. An unpublished study of a Bioferia in Huancayo, a tourist destination in the Andean highlands, found significant
} 
most widely recognized, well-attended, and lucrative is the Bioferia in Miraflores. This particular market was established in 1999 with the support of an influential NGO called Grupo Eco-lógico. According to Aponte (2013), ${ }^{9}$ the organizers had to overcome the stigma associated with outdoor markets among the more affluent population who perceived these markets as "noisy" and "chaotic." Unofficial estimates are that the market takes in about 1 million soles a year (about US $\$ 335,000) .{ }^{10}$ In 2009 there were 50 vendors in 48 stands at the market composed of associations and individual producers as well as agro-food processors. It is estimated that there are around 1,000 farmers represented at the market through the various associations. Farmers and farmer associations from all over Peru are drawn to this market where they charge prices up to $30 \%$ higher than in nondifferentiated markets. This particular Bioferia is the only one of its kind where all the vendors are certified by a third party, such as BioLatina. Other Bioferias in more remote locations utilize the Participatory Guarantee Systems, certification systems based on "participation of stakeholders [that] are built on a foundation of trust, social networks and knowledge exchange" (IFOAM Organics International, 2014). PGS are in some ways an institutionalized version of the social embeddedness associated with FMs in the U.S. (Hinrichs, 2000; Sage, 2003).

Customers at the Bioferia reflect the demographics of this area: affluent Peruvians and tourists from Europe and North America for whom Miraflores is a popular destination in Lima. According to one vendor with whom I spoke, customers inquire about the origins and qualities of the produce, but never about the price. Customers appreciate the fact that there is a marketplace

limitations to their organic market due to poor organization and marketing, coupled with a lack of supply of organic goods, and a lack of consumers willing and able to pay for organic produce (Loomis, 2010).

${ }^{9}$ Data drawn from W.V. Castro Aponte (2013) will be featured prominently in the following sections on "Las Bioferias" and "Organic NGOs in Peru."

${ }^{10}$ According to a report by USDA's Global Agriculture Information Network (GAIN) on Peru's organic sector, domestic sales of certified organic products reached US\$500,000 in 2003 (Olsen, 2008). providing certified organic produce, a distinction rarely made in other produce markets in Peru. The notions that organic produce is healthier than its conventionally grown counterparts, and that price was less relevant, were common themes that emerged in my conversations with vendors.

\section{Organic NGOs in Peru}

The Bioferia in Miraflores and much of the domestic market for organic agriculture in Peru has been made possible in part by an active NGO sector with ties to the international development community. The international development community has joined forces with Peruvian NGOs and smallfarmer advocates to promote an organic sector designed to improve farmer livelihoods and create a domestic market for their products. Beginning in the middle 1980s, a number of NGOs that promote organic production began to emerge in Peru. These NGOs operate in conjunction with other NGOs in the country and are affiliated with global and international organic and agroecological movements. Organic NGOs' missions (to promote the production and consumption of organic produce) are similar; however, they differ in the degree to which producers have leadership roles within the organization and in the amount of direct farmer training they provide (Aponte, 2013). What is most striking, however, is that they have all converged on one particular strategy, to varying degrees: encouraging farmers to adopt organic methods of production as a way to get better prices for their products.

The predominance of NGOs in the promotion of organic agriculture follows trends in the development sector more broadly in Peru, which has seen a rise in civil society networks since the era of privatization beginning in the 1990s (Bebbington, 2001, 2004; Ortiz, 2006). During this time, NGO orientations began to shift from technical innovations "to entrepreneurial approaches prioritizing access to markets" (Ortiz, 2006, p. 484). This has certainly been the trend among the organic NGOs in Peru. They have, according to Aponte (2013), played a key role in establishing organic markets by "providing funding for the Bioferias, organizing training on organic farming techniques and on certification schemes, coordinating with municipali- 
ties, and influencing policy makers for institutionalizing the Bioferias" (p. 86).

One NGO in particular, Huayuna, was instrumental in training and organizing organic farmers in the region where the present research was conducted. Nonetheless, according to an agronomist with the organization, "the principal focus [of Huayuna] is the market... We focus on the market because in the end the necessity of the producer is to earn money." Price premiums for organic produce were seen as an ideal way to improve farmer livelihoods in this region less than two hours south of Lima. The farmers they work with were already involved in markets for commodities that were becoming increasingly less reliable, like cotton and apples, both of which are commonly grown using chemical fertilizers and pesticides that are associated with negative health and environmental impacts. The creation of an organic market was seen as a way to both reduce the negative impacts of conventionally grown produce and support a vulnerable population of farmers whose preexisting markets were being threatened by overseas competition (Finan, 2007).

Both the organic NGOs and the Bioferias are evidence of a growing organic movement in Peru. An organic discourse has found its way into mainstream culture through events like La Mistura, and into the political sphere through laws banning GMOs and promoting organic agriculture. These characteristics of what could be considered an emergent AFN in Peru are in some ways comparable to developments in Northern-based AFNs: the emphasis on market-based agrarian change, privileging of producer livelihoods over low-income consumers, and dependence on an affluent consumer base that can afford to pay organic price premiums. Just as these developments have been problematized in the U.S. (Alkon, 2008; Allen 2004; Guthman 2008; Guthman et al., 2006), the Bioferia in Miraflores presents similar challenges and limitations that are, nevertheless, conditioned by the distinct Peruvian context.

\section{Awareness Does Not Equal Access: Limitations of the Organic Market}

Farmers at the Bioferia and the NGOs promoting organics have come up against various constraints to the growth of the organic market and the sustainability of institutional frameworks supporting the organic sector. Challenges associated with the domestic organic market mentioned by representatives of various organic NGOs and pioneering organic farmers include a lack of awareness and/or knowledge by both consumers and producers, a lack of consumers due to the relatively small affluent population willing and able to pay organic premiums, and challenges around the institutional sustainability of NGOs and producer cooperatives. These challenges are linked to deeper structural challenges like systemic poverty, inequality, and the lack of state support for small-scale farmers, issues that are not necessarily being addressed by promoting organic farmers markets.

The greatest challenge to the growth of the organic market, according to interviews conducted with organic farmers, organizers, and NGO leaders, is a lack of awareness on the part of both producers and consumers. In an interview conducted with the executive director of ANPE, he said that many of the campesinos (peasant farmers) they work with lack awareness about how to improve their economic situation and how to add value to their products. Helping farmers find ways to commercialize their products is an important goal of each of the organic NGOs. Up until this point, the main commercial strategy has been to develop and promote the Bioferias, with additional efforts going toward the creation of producer cooperatives better able to supply wholesale markets.

An agronomist for Huayuna expressed a similar sentiment about a lack of awareness among producers, some of whom had to be convinced of the benefits of organic beyond the price point. In a simplified account of farmer motivations, she said:

I think that here in Peru there are two types of organic producers, one that enters with awareness, without much convincing, and the other that enters because they have expectations that the price will be better than conventional. I think the majority enter for this reason.

If indeed the majority of organic farmers enter the organic market due to economic motivations, 
this does not bode well for the sustainability of organic agriculture in the region, as prices will tend to come down as more producers enter the market.

It is not just a lack of awareness on the part of producers, or their short-sighted economic motivations, that may stifle the growth of the organic market. Consumers also have an important role to play. The agronomist for Huayuna said a major problem for the organic market is:

a lack of awareness by consumers about the quality of the product. [Organic] is a better quality product. But this is a characteristic that is not concrete. You have to accept this in your head, that it is better quality. This is the work we have to do at the consumer level. This is what is missing, in my opinion. There is a group of consumers, but very few.

How then to convince consumers that there are intangible benefits to eating organic produce, especially when they can buy conventional produce that appears the same for a fraction of the cost down the street? Organic farmers and alternative food advocates face similar challenges in the U.S. Consumers need to believe that the organic product is somehow superior and be able and willing to pay for the difference in quality. According to the same agronomist, who has been working in the field of organics since the late 1990s, "Only in the market in Miraflores can they afford to pay these prices. Nobody else can pay. Nobody else is going to pay." Indeed, other Bioferias in Lima have proven less economically successful, and even greater challenges emerge in the case of a rural Bioferia in the Andes regarding insufficient supply of and demand for organic produce (Loomis, 2010).

In addition to the NGO representatives, pioneering organic farmers and cooperative members expressed concerns about the long-term viability of domestic organic markets. One such farmer, Pablo, described what he saw as some of the primary challenges facing organic producers in the region. One concern was the costly certification process, which for one cooperative was about US $\$ 900$ per year for the group. Others have shown certification to be a high barrier for small-scale farmers wanting to enter the organic market, especially those interested in exporting their products (Barrett, Browne, Harris, \& Cadoret, 2002; Raynolds, 2004). Another farmer, Juan, acknowledged the tremendous growth of the organic market in Lima, but also recognized that the lack of knowledge among consumers and of differentiated markets spaces were limiting the growth of the organic sector. He said that many farmers send their organic products with the highest quality grade to the Bioferia and the rest to a common market where the organic certification is essentially meaningless, at least in terms of a price premium. He still took satisfaction in knowing that he was growing and selling what he called a "healthier" product, regardless of the final destination.

Another concern expressed by Pablo, an organizer of the Biofrut organic cooperative, was the "sustainability of the institutions" built up to serve an organic market. This particular cooperative, for example, went from about 10 members in 1998 to only 5 members in 2013. Pablo was concerned that there would be no one to continue his legacy and that of the other organic pioneers: "What interests me most is the sustainability of organic agriculture." Pablo's concern, in part, was that organic agriculture would not persist in the region given the incentives for using synthetic fertilizers and pesticides that produce more immediate short-term gains via higher yields. According to interviews with cooperative members, organic apple producers (apples are the most common organic product in the region) have to compete with up to $40 \%$ lower yields than their conventional counterparts, in addition to having fewer marketing outlets for their produce. They say they are able to compete by selling a higher quality product at a better price.

As further indication of a lack institutional sustainability, during the course of this fieldwork news began to spread that the European NGOs funding Huayuna were defunding the organic training program and demonstration farm, choosing instead to focus their efforts in Africa. Employees of the NGO who worked on the demonstration farm and with the cooperatives were in jeopardy of losing their jobs, and the farm itself was in jeopardy of 
being dismantled. ${ }^{11}$ Because this particular NGO has been instrumental in training new farmers in organic methods of production, its absence in the region could further jeopardize the creation of new organic farmers and marketing strategies to sell their produce. ${ }^{12}$ While farmer field schools and farmer-to-farmer-like exchange programs exist in Peru (Godtland, Sadoulet, Janvry, Murgai, \& Ortiz, 2004), which may safeguard against this type of NGO withdrawal by empowering farmers to generate and share knowledge among one another, these types of organizations appear to be more active in the Andean highlands with a greater emphasis on improving subsistence production over market integration. Farmers in this coastal region of Peru, however, have historically been linked into markets for commodities like cotton, and more recently to various fresh fruits and vegetables, especially asparagus (Escobal, Agreda, \& Reardon, 2000; Finan, 2007), making them more attractive to NGOs interested in helping farmers establish new marketing opportunities.

\section{Emergent Opportunities: Organic Entrepreneurs and Rural Development}

Despite the challenges posed by the creation of an organic market that caters to an affluent clientele, the Bioferia also presents a number of opportunities for individual entrepreneurs and farmers in rural communities far from the point of sale. Organic NGOs have been instrumental in creating and supporting the organic market, but the knowledge and dedication of organic producers is what makes this market possible. Examples of a cooperative of organic farmers and a value-added dairy operation show how the Bioferia provides a space for the expression of social and ecological values previously subsumed by more conventional marketing outlets.

\footnotetext{
11 The demonstration farm is located a few hundred feet above the valley floor and is irrigated by a rather costly pump that sends water to a tank located high above the farm. Gravity is then used to irrigate the crops. Without the NGO to pay the electricity bills, it seemed unlikely that the water would continue to flow.

12 Since this research was conducted it remains unclear the extent to which Huayuna maintains an active presence in the region.
}

In the district of Mala, south of Lima, existing organic farmers were able to benefit from the commercialization of organic agriculture by establishing multiple organic cooperatives. Pablo is one of the "organic pioneers" who began working with the NGO Huayuna in the late 1990s to help develop an organic sector, which for him is still predicated on ecological values passed down from previous generations and not purely on economic incentives. He was one of the first farmers to become involved with Huayuna, was one of the first to be certified organic by Bio Latina, and is a founding member of the organic growers' cooperative. He describes his initial interaction with a Huayuna representative at a meeting of agronomists this way:

They always talked to us in the classes because we always farmed in a traditional manner. Ancestrally, our parents, they made us do work in line with lunar rotations, the sun cycle, a series of factors that we took into account. But we never knew why we did these things, scientifically...We only saw that it gave us results. So, [the representative] invited us [to the meeting]. To me it seemed interesting because all the knowledge I received from my grandfather, there are practices that I did, and I realized why I did these things.

For him, the organic methods of production replaced the traditional methods, whereas for other farmers, traditional practices were replaced with conventional ones. He continued to work with Huayuna, demonstrating what was possible with these traditional methods, which further inspired the trainings and workshops on organic agriculture on topics like integrated pest management and crop rotations.

For Pablo and the other founding members of the Biofrut cooperative, the economic incentive was not their primary motivation for growing organic fruits and vegetables. He said that for the group, "the organic [ecologica] for us is a living philosophy." He takes a holistic approach to farming, one governed by a deep understanding of ecology, including how livestock, orchards, and vegetable produc- 
tion work together. The cooperative was formed to make a case for this holistic type of farming as much as for the economic benefits of organic agriculture. According to Pablo:

We began in Biofrut with a difficult challenge. We didn't start to go into business. We organized to show how you could do organic agriculture, not for business. We showed Huayuna it was possible to grow these things. Before this, Huayuna was not interested in organic agriculture, not at all. We demonstrated it was possible. This was our reason to be, our philosophy, knowledge of country, climate, pests, soil. They saw we know all these things and said we should enter the market.

This may have been the case in the early days of the cooperative, with a consensus among members about a deeper set of ecological/organic values they brought to the table. According to an interview with one of the main organizers of the cooperative, many members ultimately left Biofrut due to the costly certification process, relatively low yields, and/or insufficient economic incentives.

Despite Biofrut's decline in membership, a different organic cooperative has seen tremendous growth in its volume of sales, mostly as a result of establishing wholesale accounts in Lima. Antonio, who has worked with Huayuna since its first trainings, projected that total sales from the cooperative could be up by fourfold over the previous year. The cooperative maintains an active presence at the Bioferia, selling mixed fruits and vegetables in relatively small volumes, but also has recently expanded its business by selling things like apples and purple corn to larger, relatively new, wholesale markets for organic produce.

In addition to fostering cooperative marketing arrangements, the Bioferia has created opportunities for a new kind of socially embedded entrepreneurialism. Scholars have applied Polanyi's concept of embeddedness to farmers markets in the U.S. (Hinrichs, 2000) and to the fair trade movement (Raynolds, 2012) to illustrate how markets can be reshaped with social and ecological concerns in mind. Gloria is one such example of an organic entrepreneur who is helping re-embed markets by linking her products and production to social and ecological, as well as economic, values. She and her family are running a small business making cheese and yogurt with milk purchased from a rural community of dairy farmers outside of Lima. They bring to the business a deep commitment to the rural community that supplies their milk and are optimistic about the potential of the market to promote more sustainable food systems. Their business has been so successful that they recently opened a "biobodega," a brick and mortar storefront where they sell their dairy products as well as local honey, olives, meats, and vegetables, creating a more permanent and visible presence within the organic food movement in Lima.

Gloria's family business offers one of the clearest examples of how the creation of organic markets can improve rural livelihoods far from the point of sale. They have formed strong social ties with members of the community, especially those inclined toward ecological agriculture. They offer farmers a good price for their milk, better than what they were getting at nearby markets. But to her, the relationship is more than one just based on an economic exchange. She said, "In reality, we share with the people of the community we live with and learn from each other, economically as well, and it is actually profitable to do so." She spoke of wanting to find other ways to support the community through things like agritourism, and of wanting to make more connections between people of the community with consumers in Lima. In speaking with dairy farmers who supply the milk for this artisan cheese and yogurt, it was clear they appreciated the opportunity to sell their milk at a good price to a reliable buyer at the point of production. Previously, they would have had to transport the milk themselves to markets up to two hours away. This case is a small, but prime, example of socially embedded entrepreneurialism that speaks to the potential of organic markets to promote rural development.

\section{An Organic Farmers Market in Peru: Challenges and Opportunities}

Challenges associated with the domestic market for 
organic produce in Peru, evident in the workings of this particular Bioferia in Miraflores, reveal some of the same challenges associated with similar markets in the U.S. The relatively high cost of organic produce at the Bioferia still puts the organic movement squarely in the domain of an affluent and healthconscious consumer base. Many key figures in the movement point to a lack of awareness by both consumers and producers of the importance of eating and growing organic produce, but no amount of awareness can compensate for a lack of access due to financial constraints. The Bioferia could have the effect of reifying organic agriculture as the domain of privileged elite, while drawing attention away from things like costly third-party certification for producers or the inability of lowincome consumers to access certified organic produce. Market-based initiatives like the Bioferia are often ill-suited to address these kinds of structural limitations. Farmers market managers in the U.S. make similar claims about a lack of awareness among consumers as a limiting factor, drawing attention away from other more practical reasons why people might not choose to shop at these kinds of markets (Guthman et al., 2006).

A unique feature of the organic landscape in Peru, compared to that of the U.S., is the predominance of organic NGOs that, on the one hand, have been invaluable in helping establish organic markets and farmer cooperatives, in addition to training new organic farmers. On the other hand, a myopic focus on the market combined with unstable funding sources may leave farmers who have come to depend on this support in jeopardy. Such organizations and farmer associations have been shown to be important to the promotion of markets for organic agriculture in developing countries (IFAD, 2003). However, reliance on the NGO sector may prove detrimental in the long run as funding sources dry up or NGOs and/or their funders shift priorities. A better strategy might be for local NGOs to facilitate the kinds of decentralized farmer-to-farmer exchanges that have proved successful in generating and sharing knowledge (Holt-Giménez, 2006; Rosset, Machin Sosa, Roque Jaime, \& Ávila Lozano, 2011). This could include knowledge about how to access and benefit from newly emerging organic markets.
In many ways, the opportunities created by the development of an organic market outweigh the limitations and negative implications associated with such high-end markets. The Bioferia expands marketing opportunities and economic incomes, conferring economic value on already existing social and ecological commitments of farmers and entrepreneurs. The market, in a broad sense, may be insufficient in instilling these non-economic values, but it does create a positive reinforcement for those who may already be interested in promoting rural development, improving farmer livelihoods, and supporting the environment. For Gloria and her family, participation in the Bioferia provided the context to incubate and grow their artisan cheese and yogurt business. The organic cooperative has benefited from the networking opportunities at the market that have opened up access to wholesale accounts. Both these findings reaffirm important benefits ascribed to FMs in U.S. scholarship that go beyond the price premium (Feenstra \& Lewis 1999, Feenstra et al., 2003; Gillespie et al., 2007).

Another potential opportunity associated with this market, and one not easily reflected in the data, pertains to the critical reflection displayed by interview subjects. According to the NGO representatives and farmers I spoke with, a lack of consumer awareness is one of the main challenges to the growth of the organic market in Peru. And yet these same individuals also recognized that Miraflores was one of the only places in the country where this kind of organic FM could be a success. They were aware that the Bioferia was not a panacea to improve livelihoods of farmers throughout the country, or a way to address the persistent poverty and inequality throughout the country. However, they continued in their efforts with the Bioferia because there were improvements being made in the lives of those farmers fortunate enough to have access to this market and to organic certifications. Their awareness is similar to the "reflexive localism" championed by Dupuis and Goodman (2005) that encourages an examination of inequalities and social justice within and among various conceptualizations of the "local." These actors, in their own ways, demonstrate critical, reflexive awareness of the possibilities and limitations of the organic mar- 
ket. This is a first step toward addressing some of the deeper structural problems facing Peruvian campesinos and urban dwellers unable to afford and/or access organic produce-issues of interest and/or awareness aside.

\section{"Reading for Difference" in Peru's Organic Farmers Market}

Despite its parallels with AFNs in the global

North, Peru's burgeoning organic sector must be studied in its distinct developing-country context, which encourages "reading for difference rather than dominance" (Gibson-Graham, 1996) in AFNs. NGOs promoting rural livelihoods in Peru are less susceptible to the criticism of AFNs in the North for being overly focused on farmers at the expense of underserved populations (Allen, 2004). This is because these NGOs are serving one of the most vulnerable populations in Peru: small-scale farmers. Organic NGOs like Huayuna that promote market integration have focused on farmers who are already dependent on the market, as opposed to mostly subsistence farmers. While the farmers in the coastal region of Peru may not be the most impoverished in the country, their reliance on shifting domestic and international markets has made them more vulnerable to global processes of agro-industrialization (Escobal et al., 2000; Finan, 2007; Reardon \& Berdegué, 2002).

Markets like the Bioferia may be ill-suited to address the root causes of broader structural issues affecting levels of poverty and inequality that require policy-level change. However, NGOs in Peru working with the Bioferia are also championing legislative reform to promote rural development. For example, ANPE has long been working to petition the government for better food security laws, and it has proposed a law that codifies the right of food sovereignty, a concept largely developed for and by peasant producers in the global South. Peru is also the first country in the Americas to ban GMOs, putting a 10-year moratorium on their use and barring the entry of GMO seeds and products into the country (Murphy, 2013).

As for consumer awareness, the gastronomy event mentioned earlier, La Mistura, is a testament to the widespread interest in celebrating distinctly Peruvian products grown by a traditional agricul- tural sector. The culinary renaissance in Peru has a tremendous amount of support among a crosssection of the population, evident in the huge numbers of attendees at this annual event. The national celebration of an incredibly diverse Peruvian cuisine evades the kind of entrenched localism found in parts of the U.S. alternative food movement, while also drawing attention to the challenges and opportunities in utilizing organic agriculture as a tool for promoting rural development.

\section{Conclusion}

This paper has argued that the Bioferia in Miraflores creates socially embedded economic opportunities for ecologically minded farmers and entrepreneurs while also promoting rural development and contributing to the growth of an organic movement in Peru. Importantly, this research expands on conceptualizations of AFNs relevant in both the global North and South, in addition to highlighting distinctive features of AFNs in a developing-country context. Interviews and participant observation with NGO representatives, organic farmers, and cooperative organizers affiliated with this particular Bioferia showed that the growth of the domestic organic-product sector in Peru is compromised by the emphasis on market-based agrarian change and consumer and producer awareness, as opposed to access. However, avoiding the temptation to view the Bioferia as yet another example of neoliberalism in AFNs (Harris, 2009), this reading shifts the focus to the possibilities for an emergent organic market in a country where a traditional farming sector is being ascribed new economic, social, and ecological value.

As the exploratory research presented here is intended to open up perspectives on AFNs in a global context, it also points to several fruitful avenues of future research. Such research would do well to consider the potential ramifications of increased competition in the domestic market for organic produce in Peru, especially given the tendency toward conventionalization in Northern markets (Buck et al., 1997; Coombs \& Campbell, 1998) and the already existing export-oriented organic sector in the global South that shares some of these tendencies (Finan, 2007; Raynolds, 2004). Survey data of organic consumers in Peru might 
also be compared with survey data among organic consumers in the global North to determine if there are unique concerns or motivations among consumers in less and more developed countries. Lastly, more research is necessary to assess the extent to which organic farming for domestic markets in Peru is a viable strategy for improving rural livelihoods. These potential research endeavors would increase dialogue and interaction between the related, but too often separated, fields of sociology of development and sociology of agriculture, thus contributing to an increasingly globalized discourse on the importance of building sustainable food systems.

\section{Acknowledgements}

The author would like to thank his dissertation committee members, in particular Julie Guthman, for their invaluable guidance during the preparation of this paper. I am also grateful for the support of the Multinational Exchange for Sustainable Agriculture and the exchange participants who made this research possible. Special thanks to Dr. Sarah T. Romano at the University of Northern Colorado, and University of Vermont Food Systems Summit conference organizers for their editorial comments and guidance during the revision process.

\section{References}

Abrahams, C. (2007). Globally useful conceptions of alternative food networks in the developing South: The case of Johannesburg's urban food supply system. In D. Maye, L. Holloway, \& M. Kneafsey (Eds.), Alternative food geographies: Representation and practice (pp. 95-114). Bingley, UK: Emerald.

Alkon, A. H. (2008). From value to values: Sustainable consumption at farmers markets. Agriculture and Human Values, 25(4), 487-498. http://dx.doi.org/10.1007/s10460-008-9136-y

Alkon, A. H., \& Mares, T. M. (2012). Food sovereignty in US food movements: Radical visions and neoliberal constraints. Agriculture and Human Values, 29(3), 347-359. http://dx.doi.org/10.1007/s10460012-9356-z

Allen, P. (2004). Together at the table: Sustainability and sustenance in the American agrifood system. University Park, Pennsylvannia: Penn State University Press.
Allen, P., \& Guthman, J. (2006). From "old school" to "farm-to-school": Neoliberalization from the ground up. Agriculture and Human V alues, 23(4), 401-415 http://dx.doi.org/10.1007/s10460-0069019-z

Allen, P., \& Kovach, M. (2000). The capitalist composition of organic: The potential of markets in fulfilling the promise of organic agriculture. Agriculture and Human Values, 17(3), 221-232. http://dx.doi.org/10.1023/A:1007640506965

Bacon, C. (2005). Confronting the coffee crisis: Can fair trade, organic, and specialty coffees reduce smallscale farmer vulnerability in northern Nicaragua? World Development, 33(3), 497-511. http://dx.doi.org/10.1016/j.worlddev.2004.10.002

Barrett, H. R., Browne, A. W., Harris, P. J. C., \& Cadoret, K. (2002). Organic certification and the UK market: Organic imports from developing countries. Food Policy, 27(4), 301-318. http://dx.doi.org/10.1016/S0306-9192(02)00036-2

Beban, A. (2014). Is organic agriculture a viable strategy in contexts of rapid agrarian transition? Evidence from Cambodia. Journal of Agriculture, Food Systems, and Community Development, 4(2), 131-147. http://dx.doi.org/10.5304/jafscd.2014.042.004

Bebbington, A. (2001). Globalized Andes? Livelihoods, landscapes and development. Cultural Geographies, 8(4), 414-436. http://dx.doi.org/10.1177/096746080100800403

Bebbington, A. (2004). NGOs and uneven development: Geographies of development intervention. Progress in Human Geography, 28(6), 725-745. http://dx.doi.org/10.1191/0309132504ph516oa

Beuchelt, T. D., \& Zeller, M. (2011). Profits and poverty: Certification's troubled link for Nicaragua's organic and fairtrade coffee producers. Ecological Economics, 70(7), 1316-1324. http://dx.doi.org/10.1016/i.ecolecon.2011.01.005

Brown, C., \& Miller, S. (2008). The impacts of local markets: A review of research on farmers markets and community supported agriculture (CSA). American Journal of Agricultural Economics, 90(5), 1298-1302. http://dx.doi.org/10.1111/j.14678276.2008.01220.x

Buck, D., Getz, C., \& Guthman, J. (1997). From farm to table: The organic vegetable commodity chain of northern California. Sociologia Ruralis, 37(1), 3-20. http://dx.doi.org/10.1111/1467-9523.00033 
Castro Aponte, W. V. (2013). Non-governmental organizations and the sustainability of small and mediumsized enterprises in Peru: An analysis of networks and discourses. Wageningen, The Netherlands: Wageningen Academic Publishers. http://dx.doi.org/10.3920/978-90-8686-783-7

Coombs, B., \& Campbell, H. (1998). Dependent reproduction of alternative modes of agriculture: Organic farming in New Zealand. Sociologia Ruralis, 38(2), 127-145. http://dx.doi.org/10.1111/1467$\underline{9523.00068}$

DeLind, L. B. (2002). Place, work, and civic agriculture: Common fields for cultivation. Agriculture and Human Values, 19(3), 217-224. http://dx.doi.org/10.1023/A:1019994728252

DuPuis, E. M., \& Goodman, D. (2005). Should we go "home" to eat? Toward a reflexive politics of localism. Journal of Rural Studies, 21(3), 359-371. http://dx.doi.org/10.1016/j.jrurstud.2005.05.011

Escobal, J., Agreda, V., \& Reardon, T. (2000). Endogenous institutional innovation and agroindustrialization on the Peruvian coast. Agricultural Economics, 23(3), 267-277. http://dx.doi.org/10.1111/j.15740862.2000.tb00278.x

Feenstra, G., \& Lewis, C. (1999). Farmers' markets offer new business opportunities for farmers. California Agriculture, 53(6), 25-29. http://dx.doi.org/10.3733/ca.v053n06p25

Feenstra, G. W., Lewis, C. C., Hinrichs, C. C., Gillespie, G. W., \& Hilchey, D. (2003). Entrepreneurial outcomes and enterprise size in US retail farmers' markets. American Journal of Alternative Agriculture, 18(1), 46-55.

Ferreira, D. (2008). Peru: Promotion of the organic or ecological production. Retrieved from the Library of Congress website: http://www.loc.gov/lawweb/servlet/ $\underline{\text { loc news?disp3 } 120540261 \text { text }}$

Finan, A. (2007). New markets, old struggles: Large and small farmers in the export agriculture of coastal Peru. The Journal of Peasant Studies, 34(2), 288-316. http://dx.doi.org/10.1080/03066150701516716

Flores, P. (2014). Organic agriculture in Latin American and the Caribbean. In H. Willer \& J. Lernoud (Eds.), The world of organic agriculture: Statistics and emerging trends 2015 (pp. 226-232). Frick, Switzerland: Research Institute of Organic Agriculture.
Freidberg, S., \& Goldstein, L. (2011). Alternative food in the global south: Reflections on a direct marketing initiative in Kenya. Journal of Rural Studies, 27(1), 24-34. http://dx.doi.org/10.1016/j.jrurstud.2010.07.003

Gillespie, G., Hilchey D. L., Hinrichs, C. C., \& Feenstra, G. (2007). Farmers' markets as keystones in rebuilding local and regional food systems. In C. C. Hinrichs \& T. A. Lyson (Eds.), Remaking the North American food system: Strategies for sustainability (pp. 6583). Lincoln, Nebraska: University of Nebraska Press.

Godtland, E. M., Sadoulet, E., De Janvry, A., Murgai, R., \& Ortiz, O. (2004). The impact of farmer field schools on knowledge and productivity: A study of potato farmers in the Peruvian Andes. Economic Development and Cultural Change, 53(1), 63-92. http://dx.doi.org/10.1086/423253

Goodman, D., \& Goodman, M. (2009). Alternative food networks. In R. Kitchin \& N. Thrift (Eds.), International encyclopedia of human geography (pp. 208220). Oxford: Elsevier.

Gibson-Graham, J. K. (1996). The end of capitalism (as we knew it): A feminist critique of political economy. Oxford, UK: Blackwell Publishers.

Gibson-Graham, J. K. (2006). A postcapitalist politics. Minneapolis, Minnesota: University of Minnesota Press.

Griffin, M. R., \& Frongillo, E. A. (2003). Experiences and perspectives of farmers from Upstate New York farmers' markets. Agriculture and Human Values, 20(2), 189-203. http://dx.doi.org/10.1023/A:1024065526440

Guthman, J. (2003). Fast food/organic food: Reflexive tastes and the making of 'yuppie chow.' Social \& Cultural Geography, 4(1), 45-58. http://dx.doi.org/10.1080/1464936032000049306

Guthman, J. (2008). Neoliberalism and the making of food politics in California. Geoforum, 39(3), 11711183. http://dx.doi.org/10.1016/i.geoforum.2006.09.002

Guthman, J., Morris, A. W., \& Allen, P. (2006). Squaring farm security and food security in two types of alternative food institutions. Rural Sociology, 71(4), 662-684. http://dx.doi.org/10.1526/003601106781262034 
Hardesty, S. D., \& Leff, P. (2010). Determining marketing costs and returns in alternative marketing channels. Renewable Agriculture and Food Systems, 25(1), 24-34. http://dx.doi.org/10.1017/S1742170509990196

Harris, E. (2009). Neoliberal subjectivities or a politics of the possible? Reading for difference in alternative food networks. Area, 41(1), 55-63. http://dx.doi.org/10.1111/j.14754762.2008.00848.x

Hinrichs, C. C. (2000). Embeddedness and local food systems: Notes on two types of direct agricultural market. Journal of Rural Studies, 16(3), 295-303. http://dx.doi.org/10.1016/S0743-0167(99)00063-7

Hinrichs, C. C., \& Allen, P. (2008). Selective patronage and social justice: Local food consumer campaigns in historical context. Journal of Agricultural and Environmental Ethics, 21(4), 329-352. http://dx.doi.org/10.1007/s10806-008-9089-6

Holt-Giménez, E. (2006). Campesino a campesino: Voices from Latin America's farmer to farmer movement for sustainable agriculture. Oakland, California: Food First Books.

IFOAM Organics International. (2014). Participatory Guarantee Systems (PGS). Retrieved June 2014, from http://www.ifoam.org/fr/value-chain/ participatory-guarantee-systems-pgs

International Fund for Agricultural Development (IFAD). (2003). The adoption of organic agriculture among small farmers in Latin America and the Caribbean: Thematic evaluation (Report No. 1337). Rome, Italy: Author.

Jaffee, D. (2007). Brewing justice: Fair trade coffee, sustainability, and survival. Oakland, California: University of California Press.

Jarosz, L. (2007). The city in the country: Growing alternative food networks in metropolitan areas. Journal of Rural Studies, 24(3), 231-244. http://dx.doi.org/10.1016/i.jrurstud.2007.10.002

Lee, R. (2000). Shelter from the storm? Geographies of regard in the worlds of horticultural consumption and production. Geoforum, 31(2), 137-157. http://dx.doi.org/10.1016/S0016-7185(99)00036-6

Loomis, J. C., \& Murray, D. L. (2010). No como veneno: Strengthening local organic markets in the Peruvian Andes (Unpublished master's thesis). Colorado State University, Fort Collins, Colorado. Retrieved from http://books.google.com/books/about/No Com o_Veneno.html?id=eomrXwAACAAJ)
Mistura. (2014). Noticias. Retrieved June 2014, from http://mistura.pe/category/noticias/

Murphy, A. (2013, April 25). Peru says no to GMO. The Christian Science Monitor. Retrieved from http://www.csmonitor.com/World/Americas/201 3/0425/Peru-says-no-to-GMO

Olsen, P. (2008). Peru organic products update 2008 (GAIN Report No. PE8014). Washington, D.C.: USDA Foreign Agriculture Service.

Organic Products and Market ("Productos ecológicos y Mercado”). (2012, August 13). Movimiento Agroecológico de América Latina y el Caribe. Retrieved from http://maela-agroecologia.org/experienciasagroecologicas/article/productos-ecologicos-ymercado

Ortiz, O. (2006). Evolution of agricultural extension and information dissemination in Peru: An historical perspective focusing on potato-related pest control. Agriculture and Human Values, 23(4), 477-489. http://dx.doi.org/10.1007/s10460-006-9014-4

Parrott, N., Olesen, J. E., \& Høgh-Jensen, H. (2006). Certified and non-certified organic farming in the developing world. In N. Halberg, H. F. Alroe, M. T. Knudsen, \& E. S. Kristensen (Eds.), Global development of organic agriculture: Challenges and promises (pp. 153-180). Wallingford, UK: CAB Publishing. http://dx.doi.org/10.1079/9781845930783.0153

Pugliese, P. (2001). Organic farming and sustainable rural development: A multifaceted and promising convergence. Sociologia Ruralis, 41(1), 112-130. http://dx.doi.org/10.1111/1467-9523.00172

Raynolds, L. T. (2004). The globalization of organic agro-food networks. World Development, 32(5), 725743. http://dx.doi.org/10.1016/j.worlddev.2003.11.008

Raynolds, L. T. (2012). Fair trade: Social regulation in global food markets. Journal of Rural Studies, 28(3), 276-287. http://dx.doi.org/10.1016/i.jrurstud.2012.03.004

Reardon, T., \& Berdegué, J. A. (2002). The rapid rise of supermarkets in Latin America: Challenges and opportunities for development. Development Policy Review, 20(4), 371-388. http://dx.doi.org/10.1111/1467-7679.00178

Renting, H., Marsden, T. K., \& Banks, J. (2003). Understanding alternative food networks: Exploring the role of short food supply chains in rural development. Environment and Planning A, 35(3), 393-411. http://dx.doi.org/10.1068/a3510 
Rosset, P. M., Machín Sosa, B., Rocque Jaime, A. M., \& Ávila Lozano, D. R. (2011). The Campesino-toCampesino agroecology movement of ANAP in Cuba: Social process methodology in the construction of sustainable peasant agriculture and food sovereignty. Journal of Peasant Studies, 38(1), 161-191. http://dx.doi.org/10.1080/03066150.2010.538584

Sage, C. (2003). Social embeddedness and relations of regard: Alternative 'good food' networks in southwest Ireland. Journal of Rural Studies, 19(1), 47-60. http://dx.doi.org/10.1016/S0743-0167(02)00044$\underline{\mathrm{X}}$

Slocum, R. (2007). Whiteness, space and alternative food practice. Geoforum, 38(3), 520-533. http://dx.doi.org/10.1016/j.geoforum.2006.10.006

Thavat, M. (2011). The tyranny of taste: The case of organic rice in Cambodia. Asia Pacific Viempoint, 52(3), 285-298. http://dx.doi.org/10.1111/j.1467$\underline{8373.2011 .01458 . x}$
Thilmany, D. D., \& Watson, P. (2004). The increasing role of direct marketing and farmers markets for western US producers. Western Economics Forum, 3(2), 19-25.

Vaarst, M. (2010). Organic farming as a development strategy: Who are interested and who are not? Journal of Sustainable Development, 3(1), 38-50. http://www.ccsenet.org/journal/index.php/jsd

Watts, D. C. H., Ilbery, B., \& Maye, D. (2005). Making reconnections in agro-food geography: Alternative systems of food provision. Progress in Human Geography, 29(1), 22-40. http://dx.doi.org/10.1191/0309132505ph526oa

Willer H., \& Lernoud, J. (Eds.). (2014). The world of organic agriculture: Statistics and emerging trends 2014. Frick, Switzerland, and Bonn, Germany: Research Institute of Organic Agriculture (FiBL) and International Federation of Organic Agriculture Movements (IFOAM). https://www.fibl.org/file admin/documents/shop/1636-organic-world2014.pdf 